\title{
Survey on Powdery Mildew of Cucumber in Aurangabad and Jalna Districts, India
}

\author{
S.M. Wahul", G.P. Jagtap, K.A. Rewale and R.P. Bhosale \\ Department of Plant Pathology, College of agriculture, Vasantrao Naik Marathwada Krishi \\ Vidyapeeth, Parbhani (MH), India \\ *Corresponding author
}

\begin{abstract}
A B S T R A C T
Cucumber (Cucumis sativus L.) is one of the most popular and favorite vegetable crops in different parts of the world. Most species are climbing perennial herbs. Cucumber contains 0.4 per cent protein, 2.5 per cent carbohydrates, $1.5 \mathrm{mg}$ iron, and $2 \mathrm{mg}$ of vitamin C in 100 $\mathrm{mg}$ of fresh weight. Powdery mildew caused by Erysiphe cichoracearum (D.C.) is an important disease of cucurbits, particularly, cucumber is highly susceptible to this disease and suffers heavy losses in all localities of Maharashtra State, wherever it is grown. Survey of Cucumber powdery mildew incidence and severity exercised in the Jalna and Aurangabad districts revealed that in Jalna district, the highest disease incidence was found on saini cultivar $(47.28 \%$ ) in Chomanwadi village of Jalna tahsil and lowest incidence was found in swati cultivar $(20.10 \%)$ in Ramnagar village of Jalna tahsil. The highest disease severity was found on gypsy (34.65\%) in Garadkheda village of Partur tahsil and lowest severity was found in Swati cultivar (10.24 \%) in Ramnager village of Jalna tahsil. The highest mean disease incidence was found in Partur tahsil (36.92 \%) and the highest mean disease severity was found in Partur tahsil (24.75\%). In case of Aurangabad district, the highest disease incidence was found in saini cultivar $(46.38 \%)$ in Harnabadwadi village of Sillod tahsil and lowest incidence was found in Saini (20.53\%) in Shendra village of Aurangabad tahsil. The highest disease severity was found in Gypsy $(29.76 \%)$ in Wahegaon village of Gangapur tahsil and lowest severity was found in saini cultivar (13.26\%) in Harsul village of Aurangabad tahsil. The highest mean disease incidence was found in Silod tahsil (35.21\%) and the highest mean disease severity was found in Vajapur tahsil (22.52\%).
\end{abstract}

\section{Introduction}

Vegetables form an essential component of human diet for maintenance of good health. They supply carbohydrates, proteins, fats, vitamins, and mineral elements which are the most essential requirements of our body. Cucumber (Cucumis sativus L.) is belongs to family cucurbitaceous is one of the most popular and favorite vegetable crops in different parts of the world. The family has two subfamilies and includes 118 genera and 825 species (Judd et al., 2008). Most species are climbing perennial herbs. The family is important for edible fruits (Heywood et al., 2007; Judd et al., 2008). It is used either as 
fresh fruits or in pickling industry. Cucumber contains 0.4 per cent protein, 2.5 per cent carbohydrates, $1.5 \mathrm{mg}$ iron, and $2 \mathrm{mg}$ of vitamin C in $100 \mathrm{mg}$ of fresh weight. Fruits are good for people suffering from constipation, jaundice and indigestion (Anonymous, 2014). Powdery mildew caused by Erysiphe cichoracearum (D.C.) is an important disease of cucurbits, particularly; cucumber is highly susceptible to this disease and suffers heavy losses in all localities of Maharashtra State, wherever it is grown. Cucumber is found wild in Himalaya and in northern India (Molen, 2007/2008). Cucumbers have been grown in India for more than 3000 years and around 2000 B.C. was brought to the area around the Mediterranean Sea and Egypt (Bjelland, 1988).

\section{Materials and Methods}

A field survey of powdery mildew of cucumber was conducted in two district of Marathawada region during the month of December and February, 2014-16 to record occurrence and distribution of powdery mildew of cucumber. On an average 10 farmer's field of cucumber in each tehsil of each district were visited and the percent powdery mildew disease incidence was recorded by counting total cucumber plant in $1 \times 1 \mathrm{~m} 2$ area and total dry root rot infected plants in that area. Cucumber plants showing typical symptoms were collected in separate paper bags and brought to the laboratory for investigations. The intensity of disease was noted by counting at least 200 plants in each field. Observation on powdery mildew intensity was recorded as, the symptoms expressed as the symptoms of the disease were first noticed on upper surface of lower leaves.

The white lesions increase in number; until they cover both leaf surfaces and stems, leaves that are seriously affected will become brown and shrunken. When young leaves are infected it can result in chlorosis. When conditions are ideal the powdery mildew can cover the whole leaf, cause leaves to die, which results in premature defoliation. Powdery mildew may also cause reduced yields with failed maturity and small and deformed. Powdery mildew can appear in most parts of the cucumber plant, but is most common in young tissues on the upper side of the leaves. Similar results are given by Sitterly (1978) and Agrios (2005).

\section{Results and Discussion}

Prevalence of Cucumber Powdery Mildew and Their Severity

Survey of powdery mildew of Jalna District.

The disease incidence ranged from 20.10 to $47.28 \%$ and the disease severity ranged from 10.24 to $34.65 \%$. The highest disease incidence was found in Saini Cultivar $(47.28 \%)$ in Chomanwadi village of Jalna tahsil and lowest incidence was found in Swati Cultivar $(20.10 \%)$ in Ramnagar village of Jalna tahsil. The highest disease severity was found in Gypsy Cultivar (34.65\%) in Garadkheda village of Partur tahsil and lowest severity was found in Swati Cultivar (10.24\%) in Ramnager village of Jalna tehsil. (Table: 1, Fig. 1).

From the survey of different Cucumber field it revealed that powdery mildew disease was predominant in region but severity was varied. From the data collected, it was observed that in spite of regular fungicidal spray powdery mildew disease occurred in Jalna district and yield also obtained therefore are subjected to fluctuation of rainfall and humidity.

The data revealed that Table 2 and Figure 2, in 2015 mean Powdery Mildew incidence and mean disease severity were observed in five Tahsils of Jalna district ranged from 27.71 to $37.83 \%$ and 16.87 to $24.75 \%$ respectively. 
Table.1 Survey of Cucumber Powdery mildew for Incidence and severity of Jalna district

\begin{tabular}{|c|c|c|c|c|c|c|}
\hline $\begin{array}{l}\text { Sr. } \\
\text { No }\end{array}$ & Tahsil & Villages & $\begin{array}{c}\text { Area } \\
\text { (ha.) }\end{array}$ & Cultivar & $\begin{array}{c}\text { Disease } \\
\text { incidence } \\
(\%)\end{array}$ & $\begin{array}{c}\text { Disease } \\
\text { severity } \\
(\%)\end{array}$ \\
\hline \multirow[t]{4}{*}{1} & \multirow[t]{4}{*}{ Jalna } & Kadvanchi & 0.20 & Saini & 45.20 & 32.34 \\
\hline & & Viregawan & 0.25 & Hanni & 42.30 & 31.60 \\
\hline & & Ramnager & 0.25 & Swati & 20.10 & 10.24 \\
\hline & & Savargawan & 0.30 & Saini & 40.10 & 22.35 \\
\hline \multirow[t]{4}{*}{2} & \multirow[t]{4}{*}{ Partur } & Amba & 0.20 & Hanni & 36.45 & 25.33 \\
\hline & & Garadkheda & 0.30 & Gypsy & 46.40 & 34.65 \\
\hline & & Amba & 0.25 & Swati & 28.30 & 18.80 \\
\hline & & Watoor & 0.15 & Gypsy & 40.20 & 20.23 \\
\hline \multirow[t]{4}{*}{3} & \multirow[t]{4}{*}{ Ghansavangi } & Shevgal & 0.10 & Gypsy & 38.33 & 18.54 \\
\hline & & Jogladevi & 0.20 & Saini & 20.16 & 14.12 \\
\hline & & Eklahra & 0.25 & Hanni & 25.31 & 20.21 \\
\hline & & Hivara & 0.35 & No-800 & 27.33 & 14.63 \\
\hline \multirow[t]{4}{*}{4} & \multirow[t]{4}{*}{ Bhokardan } & Kedarkheda & 0.20 & Gypsy & 22.18 & 12.31 \\
\hline & & Rajur & 0.35 & Hanni & 33.12 & 13.60 \\
\hline & & Chormanwadi & 0.25 & Saini & 47.28 & 28.66 \\
\hline & & Gokulwadi & 0.10 & Gypsy & 34.42 & 21.22 \\
\hline \multirow[t]{4}{*}{5} & \multirow[t]{4}{*}{ Ambad } & Antarwali & 0.20 & Saini & 32.20 & 23.10 \\
\hline & & Bangaon & 0.15 & No-800 & 28.60 & 20.36 \\
\hline & & Ambad & 0.25 & Hanni & 26.45 & 15.30 \\
\hline & & Ramnagar & 0.20 & Saini & 23.61 & 11.66 \\
\hline
\end{tabular}

Table.2 Mean of disease incidence and severity in Tahsils of Jalna

\begin{tabular}{|c|l|c|c|}
\hline Sr. no. & Tahsil & Mean Disease Incidence (\%) & Mean Disease severity (\%) \\
\hline 1 & Jalna & 36.92 & 24.13 \\
\hline 2 & Partur & 37.83 & 24.75 \\
\hline 3 & Ghansavangi & 27.78 & 16.87 \\
\hline 4 & Bokardan & 34.25 & 18.94 \\
\hline 5 & Ambad & 27.71 & 17.60 \\
\hline
\end{tabular}


Table.3 Survey of cucumber powdery mildew for incidence and severity 2015 of Aurangabad district

\begin{tabular}{|c|c|c|c|c|c|c|}
\hline $\begin{array}{l}\text { Sr. } \\
\text { No }\end{array}$ & Tahsil & Village & $\begin{array}{c}\text { Area } \\
\text { (ha.) }\end{array}$ & Cultivar & $\begin{array}{c}\text { Disease } \\
\text { incidence } \\
(\%)\end{array}$ & $\begin{array}{c}\text { Disease } \\
\text { severity } \\
(\%)\end{array}$ \\
\hline \multirow[t]{4}{*}{1} & \multirow[t]{4}{*}{ Aurangabad } & Harsul & 0.25 & Saini & 30.23 & 13.26 \\
\hline & & Karmad & 0.20 & Gypsy & 36.20 & 23.12 \\
\hline & & Sendra & 0.15 & Saini & 20.12 & 14.30 \\
\hline & & Malegaon & 0.30 & Hanni & 44.20 & 28.23 \\
\hline \multirow[t]{4}{*}{2} & \multirow[t]{4}{*}{ Silod } & Golegaon & 0.20 & Saini & 23.20 & 15.56 \\
\hline & & Lehakedi & 0.20 & Gypsy & 36.12 & 22.30 \\
\hline & & Palodha & 0.15 & Swati & 35.16 & 18.42 \\
\hline & & Harnabadwadi & 0.20 & Saini & 46.38 & 26.15 \\
\hline \multirow[t]{4}{*}{3} & \multirow[t]{4}{*}{ Vaijapur } & Dahegaon & 0.25 & Gypsy & 43.20 & 34.21 \\
\hline & & Pimpalgaon & 0.10 & Gypsy & 26.31 & 18.20 \\
\hline & & Golwadi & 0.15 & Hanni & 35.46 & 21.40 \\
\hline & & Bendwadi & 0.20 & Saini & 28.30 & 16.30 \\
\hline \multirow[t]{4}{*}{4} & \multirow[t]{4}{*}{ Gangapur } & Sirasgaon & 0.25 & Saini & 34.30 & 22.61 \\
\hline & & Lasurstation & 0.20 & Gypsy & 37.12 & 24.21 \\
\hline & & Gangapur & 0.15 & N0-800 & 39.12 & 27.53 \\
\hline & & Wahegaon & 0.10 & Gypsy & 41.22 & 29.76 \\
\hline \multirow[t]{4}{*}{5} & \multirow[t]{4}{*}{ Phulambari } & Takali & 0.25 & Saini & 22.75 & 19.66 \\
\hline & & Pathri & 0.10 & Gypsy & 33.61 & 28.13 \\
\hline & & Khamgaon & 0.20 & Hanni & 31.20 & 18.20 \\
\hline & & Wadodbazar & 0.15 & Sainis & 28.46 & 17.15 \\
\hline
\end{tabular}

Table.4 Mean of disease incidence and severity in Tahsils of Aurangabad

\begin{tabular}{|r|l|c|c|}
\hline $\begin{array}{c}\text { Sr. } \\
\text { No. }\end{array}$ & \multicolumn{1}{|c|}{ Tahsil } & Mean Disease Incidence (\%) & Mean Disease severity (\%) \\
\hline $\mathbf{1}$ & Aurangabad & 32.68 & 19.72 \\
\hline $\mathbf{2}$ & Silod & 35.21 & 20.60 \\
\hline $\mathbf{3}$ & Vaijapur & 33.31 & 22.52 \\
\hline $\mathbf{4}$ & Gangapur & 37.94 & 20.02 \\
\hline $\mathbf{5}$ & Phulambari & 29.00 & 20.78 \\
\hline
\end{tabular}




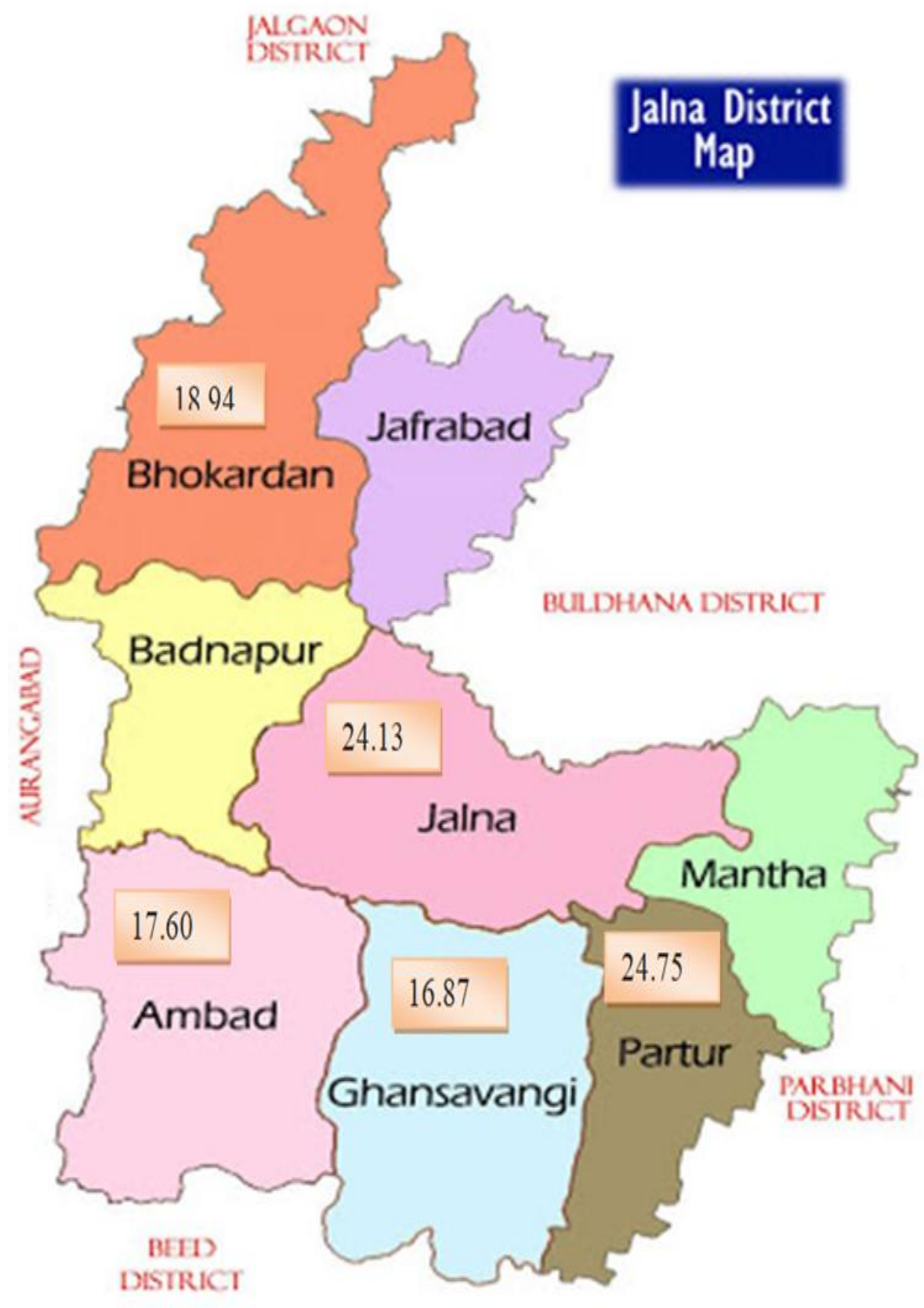

Fig. 1 -Map of Tahsils Surveyed in Jalna district showed Powdery mildew disease severity 


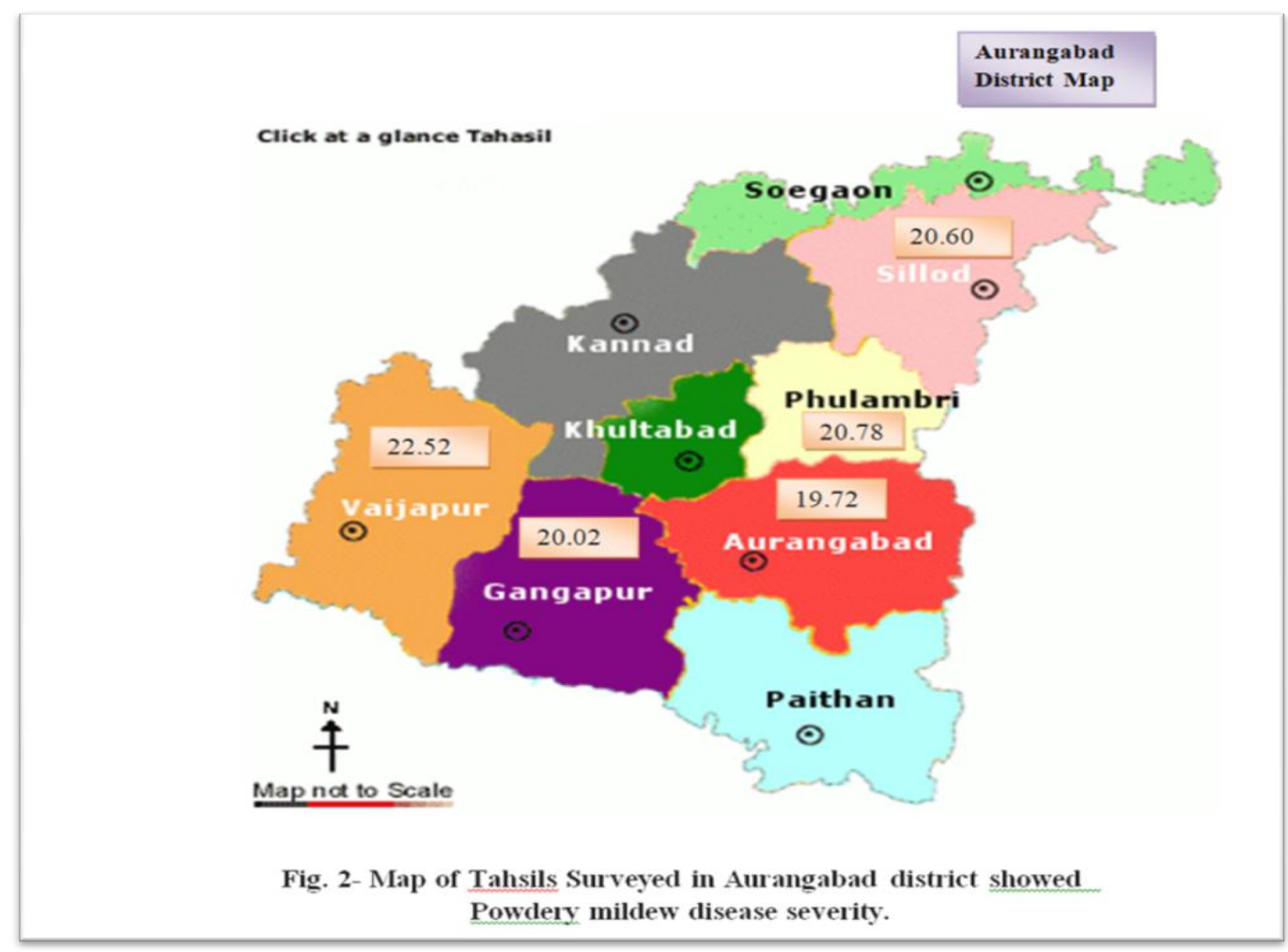

The highest mean disease incidence was found in Partur tahsil (36.92\%) and lowest mean incidence was found in Ghansavangi tahsil (17.60\%). The highest mean disease severity was found in Partur tahsil $(24.75 \%)$ and lowest severity was found in Ghansavangi tahsil (16.87\%).

\section{Survey of powdery mildew of Aurangabad District}

The disease incidence ranged from 20.12 to $46.38 \%$ and the disease severity ranged from 13.26 to $29.76 \%$. The highest disease incidence was found in Saini Cultivar $(46.38 \%)$ in Harnabadwadi village of Sillod tahsil and lowest incidence was found in Saini cultivar $(20.53 \%)$ in Shendra village of Aurangbad tahsil. The highest disease severity was found in Gypsy (29.76\%) in Wahegaon village Gangapur tahsil and lowest severity was found in Saini (13.26\%) Harsul village of Auragabad tahsil (Table 3 and Fig. 2).
The data revealed that (Table 4) in this year mean disease incidence and mean disease severity were observed in five tahsils of Aurangabad district were ranged from 29 to $35.21 \%$ and 19.72 to $22.52 \%$ respectively. The highest mean disease incidence was found in Silod tahsil $(35.21 \%)$ and lowest mean incidence was found in Phulambari tahsil (29\%). The highest mean disease severity was found in Vaijapur tahsil $(22.52 \%)$ and lowest severity was found in Auragabad tahsil (19.72\%).

Results of the present investigation correlates with the results of earlier worker of, Uppal et al., (1939), Tarr (1987), Shidhar and Sinha (1989) and Rana et al., (2006), Anonymous (2007-8) and Gore (2008).

Survey of Cucumber powdery mildew incidence and severity exercised in the Jalna and Aurangabad districts revealed that in Jalna district, the highest disease incidence was found on saini cultivar $(47.28 \%)$ in Chomanwadi village of Jalna tahsil and 
lowest incidence was found in swati cultivar (20.10 \%) in Ramnagar village of Jalna tahsil.

The highest disease severity was found on gypsy $(34.65 \%)$ in Garadkheda village of Partur tahsil and lowest severity was found in Swati cultivar (10.24 \%) in Ramnager village of Jalna tahsil.

The highest mean disease incidence was found in Partur tahsil (36.92 \%) and the highest mean disease severity was found in Partur tahsil (24.75 \%). In case of Aurangabad district, the highest disease incidence was found in saini cultivar (46.38 $\%$ ) in Harnabadwadi village of Sillod tahsil and lowest incidence was found in Saini $(20.53 \%)$ in Shendra village of Aurangabad tahsil. The highest disease severity was found in Gypsy (29.76\%) in Wahegaon village of Gangapur tahsil and lowest severity was found in saini cultivar (13.26\%) in Harsul village of Aurangabad tahsil. The highest mean disease incidence was found in Silod tahsil $(35.21 \%)$ and the highest mean disease severity was found in Vajapur tahsil (22.52\%).

\section{References}

Anonymous (2007). Sunflower Annual progress report, AICRP, (Sunflower) Directorate of Oilseed Research, Hyderabad PP: 151-154.

Anonymous (2008). Sunflower Annual Progress report, AICRP (Sunflower) Directorate of Oilseed Research, Hyderabad pp: 138-165.

Gore, Y. P. (2008). Investigation on Sunflower Powdery mildew. M sc.
(Agri.) Thesis (Unpub) Submitted to M.A.U., Parbhani.

Gupta, M.K. and Sharma, G.K. (2012). Studies on the dynamics of powdery mldew on cucubits in Haryana, India. Indian J.Sci.Res 3(1):101-106.

Heywood, V. H., Brummitt, R. K., Culham, A. and Seberg, O. (2007) Flowering Plant Families of the World. Ontario: Firefly Books. In English.

Judd, W. S., Campbell, C. S., Kellogg, E. A., Stevens, P. F. and Donoghue, M. J. (2008) Plant Systematics A Phylogenetic Approach Third Edition. Sunderland, Massachusetts: Sinauer Associates, Inc. In English.

Molén, S. A. (2007/2008) Ekologisk odling av växthusgurka. In: Ekologisk odling $i$ växthus. Page 1-30. Jordbruksverket. In Swedish

Rossi, C.E., Bacchi, L.M.A., Occhiena, E.M. and Watanabe, A. (1989). Chemical control of powdery mildew (Erysiphe cichoracearum) on okra. Ecossistema, 14: 110-113.

Shridhar, T. S. and Sinha, P. (1989). Assessment of loss caused by powdery mildew (Erysiphe cichoracearum) of okra (Hibiscus esculentus) and it's control. Ind. J. Agric. Sci., 59 (9) 606607.

Tarr, S.A.J. (1950). Plant Pathology Research Review Division, Nainist. Agric. Sudan., 1949-50, pp 46-55. (Abs. R.A.M., 33 No.416, 1954).

Uppal, B.N., Patel, M.K. and Kamat, M.N. (1939). The fungi of Bombay, Department of Agril. Bombay. No. 176:5.

\section{How to cite this article:}

Wahul, S.M., G.P. Jagtap, K.A. Rewale and Bhosale, R.P. 2018. Survey on Powdery Mildew of Cucumber in Aurangabad and Jalna Districts, India. Int.J.Curr.Microbiol.App.Sci. 7(10): 16181624. doi: https://doi.org/10.20546/ijcmas.2018.710.183 